\title{
Efektivitas Krim Ekstrak Buah Naga Merah (Hylocereus polyrhizus) dalam Meningkatkan Jumlah Sel Fibroblas Luka Bakar Derajat II pada Tikus Putih (Rattus norvegicus)
}

\section{Effectiveness of Red Dragon Fruit (Hylocerus polyrhizus) Extrcact Cream on Increasing Amount of Fibroblast Cells in Second Degree Burns of Albino Rats (Rattus norvegicus)}

\author{
Nurmitasari Rahmadhani ${ }^{*}$, Ira Sari Yudaniayanti², Amung Logam Saputro ${ }^{2}$, \\ Nusdianto Triakoso ${ }^{2}$, Prima Ayu Wibawati ${ }^{3}$, Aditya Yudhana ${ }^{4}$ \\ ${ }^{1}$ Bachelor of Veterinary Medicine, ${ }^{2}$ Department of Clinic and Animal Hospital, \\ ${ }^{3}$ Department of Veterinary Public Health, ${ }^{4}$ Department of Parasitology, \\ Faculty of Veterinary Medicine, Universitas Airlangga, \\ UNAIR-C Campus Mulyorejo, Surabaya, Jawa Timur, Indonesia 60115 \\ *Corresponding author: nurmitasari.rahmadhani-2015@ @kh.unair.ac.id
}

\begin{abstract}
Abstrak
Tujuan penelitian ini adalah untuk mengetahui efektivitas krim ekstrak buah naga merah (Hylocereus polyrhizus) dalam meningkatkan jumlah sel fibroblas luka bakar derajat II pada tikus putih (Rattus novegicus). Dua puluh ekor tikus putih (Rattus novegicus) jantan dibagi menjadi lima kelompok perlakuan dengan jumlah empat ulangan setiap kelompok. Semua tikus tersebut diinduksi dengan luka bakar derajat II. Kelompok kontrol negatif (K-) diterapi dengan basis krim minyak dalam air, Kelompok kontrol positif $(\mathrm{K}+)$ diterapi dengan Bioplacenton ${ }^{\circledR}$, kelompok perlakuan diterapi dengan krim ekstrak buah naga merah (Hylocereus polyrhizus) dengan konsentrasi P1 7.5\%, P2 15\%, dan P3 30\%. Terapi diberikan dua kali dalam sehari selama 10 hari. Hasil uji Kolmogorov-Smirnov menunjukkan data terdistribusi normal $(\mathrm{p}>0.05)$ dilanjutkan dengan uji Oneway ANOVA yang menunjukkan adanya perbedaan nyata dari tiap kelompok perlakuan $(\mathrm{p}<0.05)$ dan dilanjutkan dengan uji Post-Hoc LSD. Rata-rata jumlah fibroblas setiap kelompok perlakuan menunjukkan bahwa kelompok K- dan K+ berbeda nyata dengan kelompok P1, P2 dan P3. Jumlah sel fibroblas terbanyak didapati pada kelompok P2. Kesimpulan dari penelitian yang telah dilakukan adalah krim ekstrak buah naga merah (Hylocereus polyrhizus) dapat meningkatkan jumlah sel fibroblas luka bakar derajat II pada tikus putih (Rattus norvegicus).
\end{abstract}

Kata kunci: derajat II, ekstrak, fibroblas, Hylocereus polyrhizus, luka bakar

Abstract

This study aimed to find out the effectiveness of red dragon fruit (Hylocereus polyrhizus) extract cream in increasing amount of fibroblast cells in second degree burns in white rats (Rattus norvegicus). Twenty male rats (Rattus novegicus) divided into five treatment groups with four repetitions respectively. All of them were induced with second degree burns. Negative control $(K-)$ group treated with oil in water cream base. Positive control $(K+)$ treated with Bioplacenton ${ }^{\circledR} . P 1, P 2$ and P3 group treated with $7.5 \%, 15 \%$ and $30 \%$ red dragon fruit (Hylocereus polyrhizus) extract cream. Therapy was given twice a day for 10 days. Kolmogorov-Smirnov test showed that the data distribution is normal $(p>0.05)$, continued with Oneway ANOVA test that showed significant different from each groups $(p<0.05)$ and continued with Post-Hoc LSD test. Average amount of fibroblast cells from each groups showed that $K$ - group and $K+$ group is significanly different from $P 1, P 2$ and P3 group. P2 group showed the highest fibroblasts amount. The conclusion of this study is red dragon fruit extract (Hylocereus polyrhizus) cream can increase the amount of fibroblast cells in second degree burns in white rat's (Rattus norvegicus) skin.

Key words: burns, extract, fibroblast, Hylocereus polyrhizus, second degree

Received: 8 Mei 2019

Revised: 18 Juni 2019

Accepted: 11 Juli 2019 


\section{PENDAHULUAN}

Luka bakar didefinisikan sebagai bentuk kerusakan jaringan akibat kontak dengan sumber panas seperti api, bahan kimia, listrik dan radiasi (Hasyim dkk., 2012). Luka bakar diklasifikasikan menjdi empat derajat sesuai dengan kedalaman trauma pada kulit yaitu luka bakar derajat I (superficial burn), luka bakar derajat II (partial thickness burn), derajat III (full thickness burn) dan derajat IV (burn extension to deep tissue) (American Burn Association, 2009). Luka bakar jarang ditemukan dalam praktik hewan kecil namun jika terjadi dapat mengakibatkan syok distributif, hipovolemik dan kardiogenik, oleh karena itu diperlukan penanganan dan terapi yang tepat agar luka bakar sembuh dengan baik (Maravelis, 2015; Masood et al., 2016).

Penyembuhan luka yang tepat diperlukan untuk pemulihan fungsi anatomi dan fungsional kulit yang terganggu akibat luka yang timbul. Proses penyembuhan luka merupakan respon biologis yang normal yang berlangsung dalam beberapa fase. Penyembuhan luka merupakan proses fisiologis tubuh yang kompleks dimana kulit atau organ memperbaiki diri setelah terluka. Terdapat tiga fase utama pada proses penyembuhan luka yaitu fase inflamasi, fase proliferatif dan fase remodelling atau fase maturasi (Nagori dan Solanki, 2011).

Fase inflamasi dimulai segera setelah kerusakan terjadi, pada fase ini mekanisme hemostatik berlangsung untuk menghentikan perdarahan pada titik luka. Fase inflamasi ditandai oleh adanya vasokontriksi dan agregat platelet untuk menginduksi pembekuan darah. Fase kedua setelah inflamasi adalah fase proliferasi yang didominasi oleh fibroblas yang berperan menghasilkan serabut kolagen sekitar 72 jam setelah luka terbentuk (Beanes et al., 2003). Fibroblas akan membentuk jaringan ikat yang baru dan memberikan kekuatan serta integritas pada luka sehingga luka dapat sembuh dengan baik. Meningkatnya jumlah sel fibroblas akan menambah jumlah serabut kolagen dan kecepetan penyembuhan luka akan meningkat (Putra dkk., 2013). Fase ketiga adalah fase remodelling dimana terjadi pembentukan serabut kolagen baru untuk menyempurnakan proses penyembuhan luka. Fase ini terjadi mulai tiga minggu setelah fase inflamasi dan dapat berlangsung hingga bertahun-tahun (Nagori dan Solanki, 2011).

Fibroblas merupakan sel dominan pada minggu pertama penyembuhan luka yang berperan mensintesis kolagen sebagai unsur utama matriks ekstraselular yang penting pada integritas luka. Meningkatnya proliferasi fibroblas maka sintesis matriks ekstraselular dan kolagen juga akan meningkat sehingga fase proliferasi berlangsung lebih cepat menuju fase maturasi dan diharapkan penyembuhan luka akan lebih cepat terjadi (Destri dkk., 2017)

Permasalahan yang sering dihadapi dalam terapi luka bakar adalah inflamasi yang berlangsung lebih lama dibandingkan dengan luka lain sehingga menyebabkan kerapuhan jaringan yang berlanjut dengan deformitas bentuk dan gangguan fungsi jaringan. Permasalahan tersebut dapat dicegah dengan tata laksana luka fase awal yang meliputi kehilangan dan atau kerusakan epitel maupun jaringan yang menjadi struktur di bawahnya (Moenajat, 2003). Penyembuhan luka bakar saat ini sering dibantu dengan Bioplacenton ${ }^{\circledR}$ yang mengandung ekstrak plasenta $10 \%$, neomycin sulfat $0,5 \%$ dan basis gel. Penggunaan Bioplacenton ${ }^{\circledR}$ pada situs luka cenderung membutuhkan jumlah yang banyak dan dapat menimbulkan iritasi pada kulit yang ditandai dengan munculnya bintik-bintik merah pada kulit (Burhanudin, 2014). Ekstrak plasenta yang terkandung dalam Bioplacenton ${ }^{\circledR}$ dapat merangsang peningkatan proliferasi sel dan neomycin sulfat bertindak sebagai anti bakteri berspektrum luas yang dapat meminimalisir peran sel radang untuk memfagosit mikroba sehingga pembersihan luka berjalan lebih cepat (Rahayu, 2016).

Terapi luka bakar menggunakan obat topikal dengan ekstrak herbal dari bahan alam saat ini sedang gencar dikembangkan (Gauglitz et. al., 2011). Penggunaan bahan alam sebagai obat menjadi pilihan karena harganya yang relatif lebih murah dan mudah didapatkan serta dinilai lebih aman digunakan. (Nagori dan Solanki, 
2011). Beberapa tumbuhan merupakan sumber yang kaya fitokimia yang dapat berperan dalam penyembuhan luka dan mengandung antioksidan, salah satunya adalah buah naga merah (Hylocereus polyrhizus). Buah naga memiliki kandungan flavonoid tinggi yang merupakan metabolit sekunder yang terdapat pada tumbuhan hijau yang merupakan senyawa fenolik alam yang menunjukkan khasiat farmakologi (Rohyami, 2008 dalam Nuari dkk., 2017). Flavonoid dapat berperan sebagai antibakteri (Thalib, 2018). Flavonoid dapat menurunkan lipid peroksidase melalui penghambatan nekrosis sel dan peningkatan vaskularisasi, aktivitas flavonoid dalam penyembuhan luka diduga karena sifat astringent dan peran sebagai antibakteri sehingga mampu meningkatkan kontraksi luka dan reepitelisasi (Ambiga et al., 2007).

Flavonoid juga berfungsi sebagai antibakteri dan antioksidan yang dapat meningkatkan aktivasi dan proliferasi fibroblas sehingga memicu pembentukan kolagen dan mempecepat penyembuhan luka (Nurdiana dkk., 2016). Perlu dilakukan penelitian tentang efektivitas krim ekstrak buah naga merah (Hylocereus polyrhizus) dalam meningkatkan jumlah sel fibroblas pada luka bakar derajat II pada tikus putih (Rattus norvegicus) berdasarkan kandungan flavonoid yang dimiliki.

\section{METODE PENELITIAN}

Penelitian eksperimental menggunakan Rancangan Acak Lengkap. Hewan percobaan yang digunakan dalam penelitian ini merupakan tikus puth (Rattus norvegicus) galur Wistar yang berasal dari Laboratorium Penelitian dan Pengujian Terpadu (LPPT) Universitas Gadjah Mada Yogyakarta. Tikus yang digunakan berkelamin jantan berusia enam sampai delapan minggu dengan berat 150-200 gram. Tikus akan dipelihara di dalam kandang individu dari box plastik dengan pakan dan minum ad libitum.

Bahan yang digunakan dalam penelitian ini adalah buah naga merah (Hylocereus polyrhizus) yang berasal dari perkebunan buah naga merah di Bululawang, Kabupaten Malang, Jawa Timur.
Ketamin, Xylazine, etanol 70\%, kasa steril, kapas, $\mathrm{NaCl}$ fisiologis, alkohol swab, sediaan basis krim minyak dalam air (M/A) (PT. Ikapharmindo Putramas), Bioplacenton ${ }^{\circledR}$, pakan dan air minum tikus, dan buffer formaline $10 \%$.

Alat yang digunakan dalam penelitian ini adalah kandang tikus, tempat pakan, tempat minum, litter dari serbuk kayu, plat berbahan alumunium dengan ukuran $2,5 \mathrm{~cm} \times 2,5 \mathrm{~cm}$, disposable syringe $1 \mathrm{ml}$ (Gidcare), silet (Gilette), penggaris, sarung tangan lateks steril, mortar dan stamper, pipet Pasteur, sudip, spaltel penyu, pot $\mathrm{krim}$, povidon iodine 10\% (Ecodine ${ }^{\circledR}$ ), pot sampel, mikroskop trinokular (Nikon Eclipse E200), dan timbangan analitik (Ohaus ${ }^{\circledR}$ PA 214).

\section{Pembuatan ekstrak}

Pembuatan ekstrak etanol buah naga merah (Hylocereus polyrhizus) menggunakan metode maserasi. 500 gram daging buah naga merah segar yang telah dikupas dan dipisahkan dengan kulitnya dipotong-potong dan dihaluskan dengan blender selama lima menit. Daging buah yang telah menjadi jus dimasukkan ke dalam toples kaca kemudian ditambah dengan etanol 70\% sebanyak satu liter kemudian diaduk lalu ditutup dan disimpan tanpa terkena cahaya matahari sambil sering diaduk. Setelah tiga hari, sampel disaring dengan hingga diperoleh larutan ekstrak cair. Maserat yang diperoleh dipekatkan dengan rotary vacuum evaporator pada suhu $33^{\circ} \mathrm{C}$ selama satu jam hingga diperoleh ekstrak cair (Maksum, 2008).

\section{Perlakuan}

Hewan coba diadaptasikan dalam satu ruangan selama tujuh hari dengan sistem kandang individu. Pemberian pakan dan minum dengan perlakuan yang sama secara ad libitum. Serbuk kayu sebagai alas kandang diganti rutin setiap dua hari sekali. Sebelum dan sesudah dilakukan adaptasi, berat badan tikus ditimbang terlebih dahulu.

Tikus yang telah diadaptasikan ditimbang berat badannya kemudian dianestesi menggunakan kombinasi Ketamin $50 \mathrm{mg} / \mathrm{kg}$ berat badan dan Xylazine $10 \mathrm{mg} / \mathrm{kg}$ berat badan 
(Flecknell, 2009) secara intramuskular. Bagian punggung tikus terlebih dahulu dicukur dengan luas $3 \times 3 \mathrm{~cm}$. Bagian yang akan diberi perlukaan didesinfeksi terlebih dahulu dengan alkohol swab dan povidon iodine. Luka bakar dibuat menggunakan plat berbahan alumunium dengan ukuran $2,5 \mathrm{~cm}$ x $2,5 \mathrm{~cm}$ yang dipanaskan dalam air mendidih dengan suhu $100^{\circ} \mathrm{C}$ selama lima menit kemudian ditempelkan pada daerah punggung di dekat vertebrae thoracalis selama 10 detik (Akhoondinasab, 2014; Paramita, 2014).

Perlakuan diberikan sesaat setelah luka diinduksi dan diberikan setiap hari pada jam yang sama hingga hari ke-10 perlakuan. Tikus pada setiap kelompok dengan masing - masing empat ulangan diberi perlakuan sebagai berikut:

Kontrol negatif (K-) adalah tikus putih dengan luka bakar derajat II diterapi dengan basis krim minyak dalam air $(\mathrm{M} / \mathrm{A})$, kontrol positif $(\mathrm{K}+)$ adalah tikus puth dengan luka bakar derajat II dan diterapi dengan Bioplacenton ${ }^{\circledR}$, P1 adalah tikus putih dengan luka bakar derajat II dan diterapi dengan ekstrak buah naga merah (Hylocereus polyrhizus) 7,5\%, P2 adalah tikus putih dengan luka bakar derajat II dan diterapi dengan krim ekstrak buah naga merah (Hylocereus polyrhizus) 15\%, P3 adalah tikus putih dengan luka bakar derajat II dan diterapi dengan krim ekstrak buah naga merah (Hylocereus polyrhizus) 30\%

\section{Perhitungan jumlah sel fibroblas}

Hasil penelitian diukur melalui pengamatan jumlah sel fibroblas pada pada luka tikus yang dieuthanasia pada hari ke-11. Hewan coba akan dieuthanasia menggunakan ketamin dengan tiga kali dosis anestesi secara intra vena atau intra peritonial (Institute of Animal Studies, 2014). Hal yang diamati adalah jumlah sel fibroblas pada luka bakar melalui pembuatan sediaan preparat histopatologi dengan pewarnaan Hematoksilin Eosin yang kemudian diamati di bawah mikroskop cahaya dengan perbesaran 400x dan dihitung jumlah sel fibroblas yang nampak pada enam lapangan pandang yang dibaca oleh dua orang ahli histologi dan patologi anatomi dengan metode double blinding. Hasil fibroblas yang teridentifikasi dari ke enam lapangan kemudian dijumlah dan dicari rataratanya (Fuadi dkk., 2015).

\section{Analisis Data}

Data penelitian yang diperoleh dari masingmasing variabel akan diuji statistika menggunakan uji normalitas KolmogorovSmirnov, kemudian dilanjutkan dengan uji Oneway ANOVA dan uji Post-Hoc LSD (Least Significant Difference). Analisis data dilakukan menggunakan program analisa statistik SPSS for windows versi 24.

\section{HASIL DAN PEMBAHASAN}

Hasil perhitungan jumlah sel fibroblas pada setiap tikus dalam kelompok perlakuan menunjukkan hasil yang berbeda (Tabel 1). Berdasarkan hasil perhitungan, kelompok kontrol negatif (K-) tidak berbeda jauh dengan kelompok kontrol positif $(\mathrm{K}+)$ namun menunjukkan perbedaan nyata terhadap kelompok P1, P2 dan P3. Jumlah sel fibroblas pada kelompok kontrol negatif (K-) yang diterapi dengan basis krim M/A menunjukkan hasil yang paling sedikit, sedangkan sel fibroblas paling banyak didapati pada kelompok P2 yang diterapi dengan krim ekstrak buah naga merah (Hylocereus polyrhizus) dengan konsentrasi $15 \%$.

Data yang diperoleh kemudian dianalisis secara statistik menggunakan uji normalitas Kolmogorov-Smirnov dan diperoleh hasil distribusi data normal ( $\mathrm{p}>0.05)$ yang selanjutnya diuji menggunakan Oneway ANOVA. Hasil uji Oneway ANOVA menunjukkan hasil $\mathrm{p}<0.05$ yang menandakan terdapat perbedaan nyata pada setiap kelompok perlakuan. Rata-rata jumlah sel fibroblas kelompok $\mathrm{K}$ - yang diterapi dengan basis krim minyak dalam air (M/A) adalah 5.98 dengan simpangan baku 1,07. Rata-rata jumlah sel fibroblas kelompok $\mathrm{K}+$ yang diterapi dengan Bioplacenton $^{\circledR}$ adalah 6.54 dengan simpangan baku 1.87. Rata-rata jumlah sel fibroblas kelompok P1 yang diterapi dengan krim ekstrak buah naga $7.5 \%$ adalah 12.53 dengan simpangan baku 2.95. Rata-rata jumlah sel fibroblas 
Tabel 1. Jumlah sel fibroblas pada setiap tikus dalam kelompok perlakuan

\begin{tabular}{cc}
\hline Kelompok pengamatan & Rata-rata \pm SD \\
\hline K- & $5.98^{\mathrm{a}} \pm 1.07$ \\
$\mathrm{~K}+$ & $6.54^{\mathrm{a}} \pm 1.87$ \\
P1 & $12.53^{\mathrm{b}} \pm 2.95$ \\
P2 & $14.66^{\mathrm{b}} \pm 3.30$ \\
P3 & $13.55^{\mathrm{b}} \pm 3.68$ \\
\hline
\end{tabular}

Superskrip berbeda pada kolom yang sama menunjukkan perbedaan signifikan $(\mathrm{p}<0.05)$

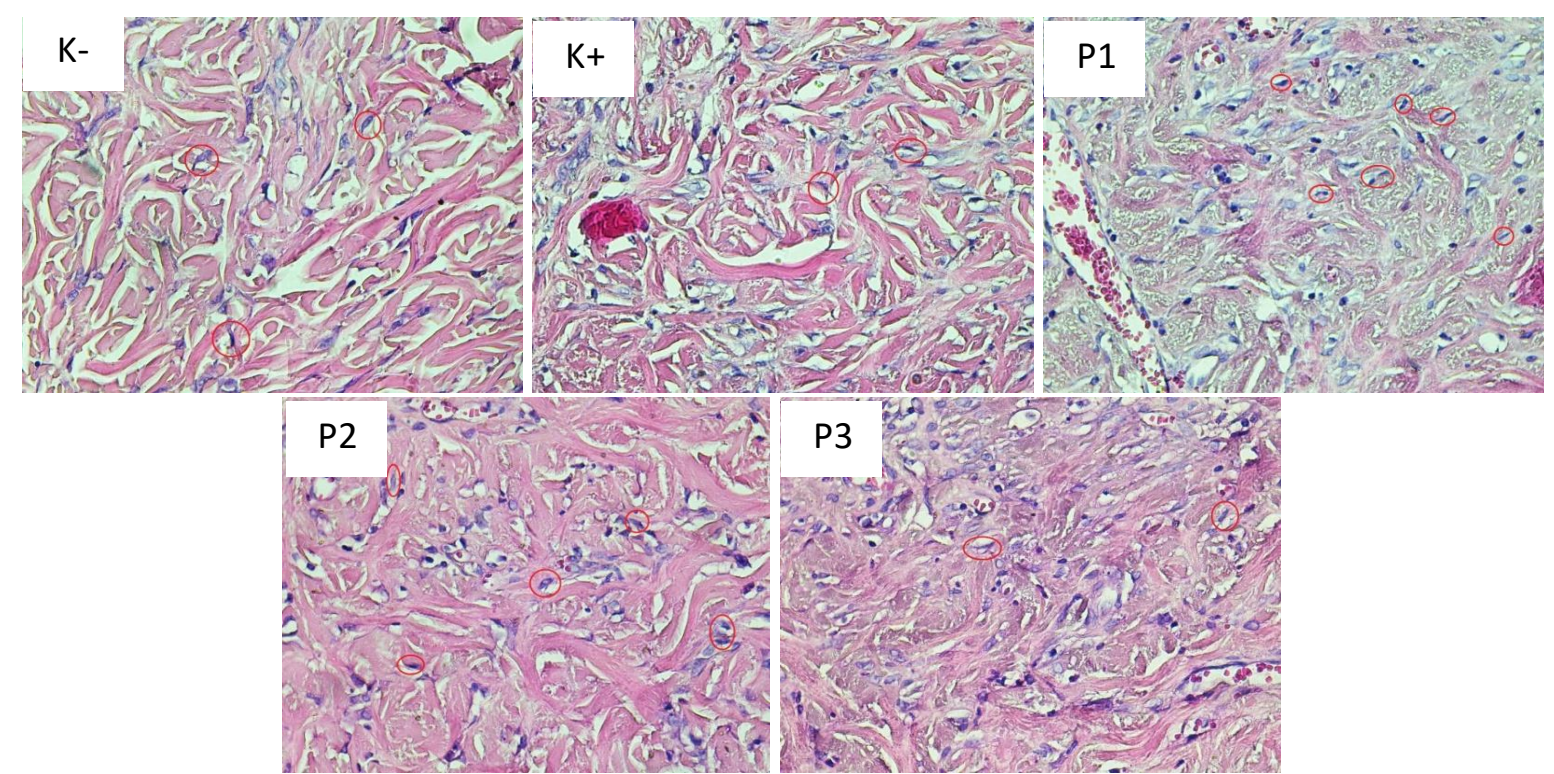

Gambar 1. Sel fibroblas (dalam lingkaran merah) dengan pewarnaan Hematoksilin Eosin diamati menggunakan mikroskop Nikon Eclipse E200 perbesaran 400x

kelompok P2 yang diterapi dengan krim ekstrak buah naga $15 \%$ adalah 14.66 dengan simpangan baku 3.30. Rata-rata jumlah sel fibroblas kelompok P1 yang diterapi dengan krim ekstrak buah naga $30 \%$ adalah 13.55 dengan simpangan baku 3.68 (Tabel 1).

Luka bakar merupakan jenis cedera yang dapat disebabkan oleh panas, suhu dingin, listrik, bahan kimia dan radiasi. Luka bakar dapat mengakibatkan kerusakan pada jaringan dan dapat menimbulkan komplikasi yang berpotensi fatal seperti syok, infeksi, terganggunya keseimbangan elektrolit dan kegagalan pernafasan. Syok yang diakibatkan oleh luka bakar ditandai dengan peningkatan permeabilitas kapiler, peningkatan tekanan hidrostatik vaskuler, migrasi cairan intravaskuler menuju ruang interstitial, menurunnya curah jantung dan hipovolemia yang terjadi akibat meningkatnya permeabilitas kapiler yang merembeskan plasma secara berlebihan ke sekitar jaringan (Evers et al., 2010; Rowan et al., 2015).

Penyembuhan luka bakar merupakan suatu proses kompleks yang dimulai dengan inflamasi, proliferasi dan remodelling. Tujuan penyembuhan luka adalah untuk mencegah invansi agen patogen, mengembalikan inetgritas jaringan yang rusak dan merekonstruksi fungsi fisiologis kulit. Namun inflamasi sistemik pada proses penyembuhan luka bakar berlangsung lebih lama daripada jenis luka yang lain karena pelepasan mediator inflamasi secara besarbesaran dari situs luka (Farina et al., 2013).

Fibroblas merupakan sel yang sering ditemukan pada jaringan ikat, berasal dari mesenkim. Sel fibroblas berperan penting dalam proses penyembuhan luka, sel tersebut akan bermigrasi ke situs luka dan ke jaringan di sekitarnya segera setelah makrofag muncul dan akan memecah jaringan disekitarnya kemudian 
digantikan dengan komponen matriks ekstraseluler terutama kolagen dan elastin. Sel fibroblas memodulasi interaksi keratinosit dengan endothel melalui produksi matriks ekstraseluler. Matriks ekstraseluler terdiri dari berbagai komponen; fibronektin berfungsi merangsang migrasi fibroblas dan kolagen serta elastin yang berperan memberikan kekuatan dan kelenturan jaringan kulit (Mescher, 2016; Jeon et al., 2010).

Jumlah sel fibroblas kelompok kontrol negatif (K-) pada penelitian ini menunjukkan hasil yang paling rendah dibandingkan dengan kelompok kontrol positif $(\mathrm{K}+)$, P1 (krim ekstrak buah naga merah (Hylocereus polyrhizus) 7.5\%), P2 (krim ekstrak buah naga merah (Hylocereus polyrhizus) 15\%) dan P3 (krim ekstrak buah naga merah (Hylocereus polyrhizus) 30\%). Kelompok kontrol negatif (K-) merupakan kelompok perlakuan tikus yang diinduksi luka bakar dan diterapi dengan basis krim minyak dalam air (M/A). Basis krim minyak dalam air (M/A) merupakan sediaan setengah padat yang terdiri dari fase minyak, fase air dan surfaktan sebagai resep standar, dan biasa digunakan sebagai bahan pembawa dari suatu zat aktif. Basis krim tipe minyak dalam air (M/A) dapat digunakan pada luka bakar karena bahan pembawa minyak dalam air cenderung menyerap cairan yang dihasilkan situs luka tersebut (Anwar, 2012).

Jumlah sel fibroblas kelompok kontrol positif $(\mathrm{K}+)$ lebih tinggi daripada kelompok kontrol negatif (K-) dan tidak menunjukkan perbedaan nyata $(p>0,05)$ namun menunjukkan hasil yang berbeda nyata $(p<0,05)$ dengan kelompok P1 (krim ekstrak buah naga merah (Hylocereus polyrhizus) 7.5\%), P2 (krim ekstrak buah naga merah (Hylocereus polyrhizus) 15\%) dan P3 (krim ekstrak buah naga merah (Hylocereus polyrhizus) 30\%). Kelompok kontrol positif $(\mathrm{K}+)$ adalah kelompok perlakuan yang diinduksi luka bakar dan diterapi dengan Bioplacenton $^{\circledR}$. Bioplacenton ${ }^{\circledR}$ adalah sediaan obat topikal yang mengandung ekstrak plasenta $10 \%$ dan antibiotik neomisin sulfat $0.5 \%$. Ekstrak plasenta dapat memicu pembentukan jaringan baru dan neomisin sulfat berguna untuk mecegah infeksi akibat bakteri Gram negatif pada situs luka (Kalbemed, 2019).

Ekstrak plasenta yang terkandung dalam Bioplacenton $^{\circledR}$ bekerja dengan mempercepat regenerasi sel dengan meningkatkan Vascular Endhotelial Growth Factor (VEGF) dan merangsang angiogenesis pada situs luka. Ekstrak plasenta mengandung banyak faktor pertumbuhan seperti Insulin Growth Factor-1 (IGF-1), Epidermal Growth Factor (EGF), Platelet-Derived Growth Factor (PDGF), Fibroblast Growth Factor-2 (FGF-2) (Hamid dkk., 2018), Vascular Endothelial Growth Factor (VEGF), Transforming Growth Factor- $\beta$ (TGF- $\beta$ ) dan zat biologis lain seperti glikosaminoglikan dan peptida (Choi et al., 2013; Hamid dkk., 2019). Antibakteri pada Bioplacenton ${ }^{\circledR}$ berasal dari kandungan neomisin sulfat. Neomisin sulfat termasuk golongan antibiotik aminoglikosida bersifat bakterisid yang bekerja dengan cara berikatan secara irreversibel dengan subunit $30 \mathrm{~S}$ pada ribosom sehingga menggangu proses translasi dan menghambat sintesis protein bakteri sehingga bakteri gagal bereplikasi dan mati (Radigan et al., 2010).

Sediaan histopatlogi kelompok kontrol positif $(\mathrm{K}+)$ tampak didominasi oleh sel radang polimorfonuklear (PMN) yang menandakan fase inflamasi masih berlangsung (Gambar 1). Sel polimorfonuklear (PMN) memiliki usia yang singkat, antara enam hingga delapan jam pada darah tepi namun bisa meningkat ketika telah bermigrasi ke situs inflamasi. Faktor terlarut dari sel Natural Killer (NK) yang diaktifkan oleh sitokin yang dirilis oleh situs luka sebagai mediator inflamasi berpotensi memperpanjang usia sel polimorfonuklear (PMN) dan mempertahankan kemampuannya dalam memfagositosis reruntuhan sel dan memproduksi Reactive Oxygen Species (ROS) (Bhatnagar et al., 2019).

Bioplacenton $^{\circledR}$ yang diaplikasikan sebagai terapi topikal pada kelompok kontrol positif $(\mathrm{K}+)$ mengandung antioksidan yang berasal dari ekstrak plasenta, namun jumlahnya belum diketahui secara pasti (Cho et al., 2008). Jumlah sel fibroblas yang sedikit pada kelompok kontrol 
positif $(\mathrm{K}+)$ diduga diakibatkan oleh aktivitas antioksidan dari Bioplacenton ${ }^{\circledR}$ yang kurang maksimal seiring dengan meningkatnya produksi Reactive Oxygen Species (ROS), sehingga kerusakan sel tidak dapat diminimalisir dan berdampak pada kerusakan sel oleh peroksidasi lipid sehingga fase inflamasi tetap bertahan dan fase proliferasi tidak segera dimulai, akibatnya jumlah fibroblas yang diproduksi masih sedikit.

Rata-rata jumlah sel fibroblas pada kelompok P1, P2 dan P3 berbeda nyata dengan kelompok kontrol negatif (K-) dan kontrol positif (K-). Hasil ini dapat terjadi karena flavonoid dan vitamin $\mathrm{C}$ yang terdapat dalam ekstrak buah naga merah (Hylocereus polyrhizus) yang berfungsi sebagai antioksidan. Flavonoid adalah senyawa alami yang disintesis oleh tumbuhan dalam jumah sedikit dan dapat ditemukan pada hampir semua bagian tumbuhan. Flavonoid merupakan senyawa aktif yang dapat meningkatkan jumlah fibroblas dan meningkatkan proliferasi sel. Flavonoid dapat meningkatkan tonus vaskuler dan melindungi dinding pembuluh darah dan berperan sebagai anti inflamasi dan antioksidan (Purnama dkk., 2018). Flavonoid memiliki potensi sebagai antioksidan karena memiliki gugus hidroksil yang terikat pada karbon cincin aromatik sehingga dapat menangkap radikal bebas yang dihasilkan reaksi peroksidasi lipid dengan cara menyumbangkan satu atom hidrogen agar radikal bebas menjadi stabil (Acar et al., 2002, Mawarti dkk., 2014 dan Dewi dkk., 2014). Flavonoid dapat berperan sebagai antibakteri dengan cara menginaktivasi protein pada membran sel sehingga pertumbuhan bakteri akan terhambat dan mencegah timbulnya infeksi sekunder (Larissa dkk., 2017). Flavonoid dapat menekan perilisan prostaglandin yang berperan sebagai mediator inflamasi sehingga jumlah sel radang yang bermigrasi ke situs luka akan berkurang (Balqis dkk., 2014).

Perilisan mediator inflamasi pada luka bakar memicu produksi dan pelepasan Reactive Oxygen Species (ROS) secara berlebihan. Perubahan oksidan lokal dan sistemik akan mengakibatkan penyumbatan neutrofil dan makrofag pada jaringan lain yang mencegah peningkatan peradangan. Akibatnya, sistem antioksidan endogen pada jaringan akan rusak dan tidak mampu mengatasi Reactive Oxygen Species (ROS) yang berlebihan secara maksimal. Peningkatan oksidan dan penurunan aktivitas antioksidan endogen akan mengakibatkan peroksidasi lipid pada membran sel. Peroksidasi lipid membran sel dapat menyebabkan perubahan likuiditas dan permeabilitas membran sel dan meningkatkan tingkat degradasi protein dan asam nukleat yang akhirnya menyebabkan sel lisis dan tidak mampu melanjutkan proses penyembuhan. Flavonoid dapat menurunkan peroksidasi lipid sehingga viabilitas serat kolagen meningkat yang didahului dengan peningkatan proliferasi fibroblas (Palumpun dkk., 2017; Zhang et al., 2014). Flavonoid dapat melindungi vitamin $\mathrm{C}$ dari Reactive Oxygen Species (ROS) dengan menghambat siklooksigenase dan lipooksigenase (Purnama dkk., 2019) sehingga jumlah sel inflamasi yang bermigrasi ke jaringan dapat berkurang dan reaksi inflamasi menjadi lebih singkat (Nugraha dkk., 2016).

Vitamin $\mathrm{C}$ atau asam askorbat penting untuk merangsang sel fibroblas pada kulit. Vitamin C mampu menetralkan Reactive Oxygen Species (ROS) dan juga berperan dalam perbaikan pembuluh darah. Aplikasi vitamin C secara topikal dapat membantu memperbaiki struktur anatomis dermal-epidermal junction dan meningkatkan aliran pembuluh kapiler yang kaya nutrisi yang dibutuhkan dalam proses penyembuhan luka bakar (Lima et al., 2009). Vitamin C juga berperan meningkatkan ekspresi gen kolagen pada sel fibroblas. Vitamin C bermigrasi melewati membran sel dengan bantuan Sodium-dependent Vitamin $C$ Transporter (SVCT) 1 dan 2. Terutama pada fibroblas yang mensitesis kolagen, SVCT 2 penting sebagai sumber penyerap vitamin $\mathrm{C}$ dari cairan ekstraseluler (Kishimoto et al., 2013). Vitamin C dapat melindungi endothel kapiler yang rusak setelah terjadi kontak dengan sumber panas dengan cara menyingkirkan Reactive Oxygen Species (ROS) yang terdapat pada ruang ekstraseluler (Rizzo et al., 2016). 
Nurdiana dkk. (2016) menyatakan bahwa semakin banyak fibroblas yang terbentuk pada proses penyembuhan, maka akan mempercepat kontraksi luka dan kesembuhan luka juga berlangsung makin cepat. Fibroblas pada situs luka akan mulai berkurang jumlahnya dan kembali normal sekitar hari ke-14 ketika matriks ekstraselular pada luka telah mencapai kekuatan regangan yang hampir sama dengan jaringan sehat di sekitarnya (Bainbridge, 2013).

\section{KESIMPULAN}

Krim ekstrak buah naga merah (Hylocereus polyrhizus) efektif dalam meningkatkan jumlah sel fibroblas luka bakar derajat II pada tikus putih.

\section{UCAPAN TERIMA KASIH}

Peneliti mengucapkan terimakasih kepada Universitas Airlangga PSDKU Banyuwangi atas izin dan fasilitas yang disediakan sebagai penunjang penelitian.

\section{DAFTAR PUSTAKA}

Acar, T., Taçyildiz, R., Vahapogxlu, H., Karakayali, S., Aydin, R. 2002. Efficiency of Micronized Flavonoid Fraction on Healing Thermally Injured Rat. J. Burns Fire Disast., 25,1 .

Akhoondinasab, M.R., Motahhare, A., Mohsen, S. 2014. Comparison of Healing Effect of Aloe Vera Extract and Silver Sulfadiazine in Burn Injuries on Experimanetal Rat Model. Faculty of Plastic and Reconstractive Surgery, Iran University of Medical Sciences, Iran. WJPS., 3(1), 29-34.

Ambiga, S., Narayanan, R., Gowri, D., Sukumar, D., Madhiavan, S. 2007. Evaluation of Wound Healing Activity of Flavonoids from Ipommoea carne Jacq. Ancient Sci. Life, 26(3), 45-51.
American Burn Association. 2009. Surgical Management of the Burn Wound and the Use of Skin Subtitutes. American Burn Association White Paper.

Anwar, E. 2012. Eksipien dalam Sediaan Farmasi: Karakteristik dan Aplikasi. Jakarta: Dian Rakyat, p.197-201.

Bainbridge, P. 2013. Wound Healing and the Role of Fibroblast. J. Wound Care, 22(8), 407-412.

Balqis, U., Rasmaidar, Marwiyah. 2014. Gambaran Histopatologis Penyembuhan Luka Bakar Menggunakan Daun Kedondong (Spodiasdulcis F.) dan Minyak Kelapa pada Tikus Puth (Rattus norvegicus). J. Med. Vet., 8(1), 31-36.

Beanes, S.R., Dang, C., Soo, C., Ting, K. 2003. Skin Repair and Scar Formation: The Central Role of TGF- $\beta$. Cammbridge University Press., 5(21), 4.

Bhatnagar, U., Hong, H.S., Krishnawamy, J.K., Haghikia, A., Behrens, G.M., Schmidt, R.E., Jacobs, R. 2019. Cytokine-activated NK Cells Inhibit PMN Apotosis and Preserve Their Functional Capacity. Blood, 116(8), 1308-1316.

Burhanudin, F.N. 2014. Uji Efektifitas Formulasi Gel Ekstrak Daun Cermai (Phyllanthus acidus L.) Terhadap Lama Kesembuhan Luka Bakar pada Kelinci (Oryctolagus cuniculus) Jantan [Skripsi]. Sekolah Tinggi Ilmu Kesehatan Ngudi Waluyo Semarang.

Cho, H., Ryou, J., Lee, J. 2008. The Effects of Placental Extract on Fibroblast Proliferation. Cosmetics Sci., 202, 195-202.

Choi, J.S., Kim, J.D., Yoon, H.S., Cho, Y.W. 2013. Full-Thickness Skin Wound Healing Using Human Placenta-Derived Extracellular Matrix Containing Bioactives 
Molecules. Tissue Engineering: Part A., 19(3-4), 329-339.

Destri, C., Sudiana, I.K., Nugraha, J. 2017. Potensi Jatropha multifida Terhadap Jumlah Fibroblas Pada Aphthous Ulcer Mukosa Mulut Tikus. J. Biosains Pascasarjana, 19(1).

Dewi, N.W.O.A.C., Puspawati, N.M., Swantara, I.M.D., Asih, I.A.R.A., Rita, W.S. 2014. Aktivitas Antioksidan Senyawa Flavonoid Ekstrak Etanol Biji Terong Belanda (Solanum betaceum, syn) Dalam Menghambat Reaksi Peroksidasi Lemak Pada Plasma Darah Tikus Wistar. Cakra Kimia. Indon. J. App. Chem., 2(1), 7-16.

Evers, L.H., Bhavsar, D., Mailänder, P. 2010. The Biology of Burn Injury. Exp. Dermatol., 19, 777-783.

Farina, J.A., Rosique, M.J., Rosique, R.G. 2013. Curbing Inflammation in Burn Patients. Int. J. Inflam., 1-9.

Flecknell, P. 2009. Laboratory Animal Anesthesia $3^{\text {rd }}$ Edition. USA. Elsevier.

Fuadi, M.I., Elfiah, U., Misnawi. 2015. Jumlah Fibroblas pada Luka Bakar Derajat II pada Tikus dengan Pemberian Gel Ekstrak Etanol Biji Kakao dan Silver Sulfadiazine. E-Jurnal Pustaka Kesehatan, 3(2), 244-248.

Gauglitz, G.G., Korting, H.C., Pavicic, T., Ruzicka, T., Jeschke, M.G. 2011. Hypertropic Scars and Keloids: Epidemiological, Clinical and Histological Differences. Mol. Med., 17(1-2), 113-125.

Hamid, I.S., Aksono, E.B., Sukmanadi, M., Purnama, M.T.E. 2018. Antiangiogenesis activity test of tin leaf (Ficus carica L.) on the number of blood vessels and VEGF expression of chorioallantoic membrane of embryonated chicken eggs. Eur. J. Oncol. Pharm., 1(4), e00007.
Hamid, I.S., Ekowati, J., Purnama, M.T.E. 2019. Kaempferia galanga $L$. Inhibiting Effect on Vascular Endothelial Growth Factor (VEGF) and Cyclooxygenase-2 (Cox-2) Expression on Endothelium of Chorioallantoic Membrane. Indian Vet. J., 96(09), 80-82.

Hasyim, N., Pare, K.L., Junaid, L., Kurniati, A. 2012. Formulasi dan Uji Efektivitas Gel Luka Bakar Ekstrak Daun Cocor Bebek (Kalanchoe pinnata L.) pada Kelinci (Oryctalagus coniculus). Majalah Farmasi dan Farmakologi, 16(2), 89-94.

Institute of Animal Studies. 2014. Recommended Methods of Anesthesia, Analgesia and Euthanasia for Laboratory Animal Species. Albert Einsten College of Medicine.

Jeon, Y.K., Jang, Y.H., Yoo, D.R., Kim, S.N., Lee, S.K., Nam, M.J. 2010. Mesenchymal Stem Cells' Interaction With Skin: Woundhealing Effect on Fibroblast Cells and Skin Tissue. Wound Rep. Reg, 18, 655-661.

Kalbemed. 2019.

http://www.kalbemed.com/ProductsDiseases/Products/Read-ProductArticle/ArtMID/458/ArticleID/179/BIOPLA CENTON. [6 Maret 2019]

Kishimoto, Y., Saito, N., Kurita, K., Shimokado, K., Maruyama, N., Ishigami, A. 2013. Asorbic Acid Enhances the Expression of Type 1 and Type 4 Collagen and SVCT2 in Cultured Human Skin Fibroblasts. Biochem. Biophys. Res. Commun., 430, 579-584.

Larissa, U.A., Wulan, J., Prabowo, A.Y. 2017. Pengaruh Binahong Terhadap Luka Bakar Derajat II. Major., 7(1), 130-134.

Lima, C.C., Pereira, A.P.C., Silva, J.R.F., Oliviera, L.S., Resk, M.C.C., Grechi, C.O., Bernardes, M.T.C.P., Olivio, F.M.P., Santos, A.M.M., Incerpi, E.K., Garcia, J.A.D. 2009. Asorbic Acid for the Healing of Skin 
Wounds in Rats. Braz. J. Biol., 69(4), 19951201.

Maksum, U. 2008. Uji Efek Anti Diabetes Ekstrak Etanol Daun Kembang Bulan (Tithonia difersifolia (hemsley) A. Gay) Terhadap Tikus yang Diinduksi Aloksan. J. Biosains, 1(2), 36-43.

Maravelis, G., Voutsinou, A., Tsampa, N., Papazoglou, L. 2015. Management of an Extensive Partial and Full Thickness Skin Burn in a Dog with the Aid of Medical Honey. Hellenic J. Companion Anim. Med., 4(2), 37-42.

Masood, R.A., Wain, Z.N., Tariq, R., Asisullah, M., Bashir, I. 2016. Burn Cases, Their Management and Complications: a Review. Int. Curr. Pharm. J., 5(12), 103-105.

Mawarti, H., Ghofar, A. 2014. Aktivitas Antioksidant Flavonoid Terhadap Perubahan Histologi Proses Penyembuhan Luka Bakar Grade II. J. Eduhealth, 4(3), 33-40.

Mescher, A.L. 2016. Histologi Dasar Junqueira: Teks dan Atlas. Jakarta: Penerbit Buku Kedokteran EGC.

Moenajat, Y. 2003. Luka Bakar dan Penanganannya Edisi Kedua. Jakarta: Balai Penerbit FKUI.

Nagori, B.P, Solanki, R. 2011. Role of Medical Plants in Wound Healing. Res. J. Med. Plant, 5(4), 392-405.

Nuari, S., Anam, S., Khumaidi, A. 2017. Isolasi dan Identifikasi Senyawa Flavonoid Ekstrak Etanol Buah Naga Merah (Hylocereus polyrhizus (F.A.C Weber) Briton \& Rose). J. Farmasi Galenika., 2(2), 118-125.

Nugraha, G.A.F., Ilmiawan, M.I., Pratiwi, S.E. 2016. Efek Pemberian Ekstrak Etanol 70\% Daun Karamunting (Rhodomyrtus tomentosa (Aiton) Hassk) Topikal Terhadap Gambaran
Histopatologi Ketebalan Serat Kolagen Penyembuhan Luka Insisi Kulit Tikus Putih Galur Wistar. Naskah Publikasi Fakultas Kedokteran Universitas Tanjungpura.

Nurdiana, I. Ulya, I.P., Putra, R.A. 2016. Pengaruh Pemberian Gel Ekstrak Daun Melati (Jasmimum sambac L. Ait) Terhadap Jumlah Fibroblas Kulit Dalam Penyembuhan Luka Bakar Derajat II A Pada Tikus Putih (Rattus norvegicus) Galur Wistar. J. Ilmu Keperawatan., 4(1), 1-11.

Palumpun, E.F., Wiraguna, A.A.G.P., Pangkahila, W. 2017. Pemberian Ekstrak Daun Sirih (Piper betle) Secara Topikal Meningkatkan Ketebalan Epidermis, Jumlah Fibroblas, dan Jumlah Kolagen Dalam Proses Penyembuhan Luka pada Tikus Jantan Galur Wistar (Rattus norvegicus). J. e-Biomed., 5(1).

Paramita, A. 2016. Pengaruh Pemberian Salep Ekstrak Daun Binahong (Anredera cordifolia (Ten) Steenis) terhadap Kepadatan Kolagen Tikus Putih (Rattus norvegicus) yangMengalami Luka Bakar [Skripsi]. Fakultas Kedokteran Hewan Universitas Airlangga. Surabaya.

Purnama, M.T.E., Prastiya, R.A., Fikri, F., Saputro, A.L., Agustono, B. 2018. Ekstrak Etanol Kulit Buah Naga Menurunkan Indikasi Neoplasia Mammae Tikus Putih Berdasarkan Histopatologi dan Inhibitor Siklooksigenase-2. J. Vet., 19(1), 23-29.

Purnama, M.T.E., Rahmaningtyas, I.H., Pratama, A.R., Prastika, Z., Kartikasari, A.M., Cahyo, N.P.D. 2019. Tadpole serum activity (Rana catesbeiana) in caspase- 3 as a marker of the role of apoptosis and total cytotoxic $\mathrm{T}$ lymphocytes in albino rats' epithelial cells induced by neoplasia. Vet. World, 12(1), 63.

Putra, A.T.W., Ade, W., Hamidy, M.Y. 2013. Tingkat Kepadatan Fibroblas pada Luka Sayat Mencit dengan Pemberian Gel Lidah 
Buaya (Aloe chinesis Baker). Bagian Patologi Anatomi dan Bagian Farmakologi Fakultas Kedokteran Universitas Riau., 6-8

Radigan, E.A., Gilchrist, N.A., Miller, M.A. 2010. Analytic Reviews: Management of Aminoglycosides in the Intensive Care Unit. J. Inten. Care Med., 1-16.

Rahayu, N. 2016. Uji Aktivitas Gel Isolat Katekin Gambir (Uncaria gambir Roxb.) Terhadap Penyembuhan Luka Bakar pada Tikus Putih Jantan Galur Sprague Dawley [Skripsi]. Fakultas Kedokteran dan Ilmu Kesehatan Universitas Islam Negeri Syarif Hidayatullah Jakarta.

Rizzo, J.A., Rowan, M.P., Driscoll, I.R., Chung, K.K., Friedman, B.C. 2016. Vitamin C in Burn Resuscitation. Crit. Care Clin., 32(4), 539-546.
Rowan, M.P., Cancio, L.P., Elster, E.A., Burmeister, D.M., Rose, L.F., Natesan, S., Chan, R.K., Christy, R.J., Chung, K.K. 2015. Burn Wound Healing and Treatment: Review and Advancement. Biomed. Central, $1-12$.

Thalib, A., Erika, K.A., Massi, M.N., Tahir, T., Mas'ud, A. 2018. Pengaruh Pemberian Krim Topikal Ekstrak Buah Naga Merah. (Hylocereus polyrhizus) pada Luka Akut Terhadap Kadar Interleukin-6 Fase Inflamasi pada Wistar. J. Luka Indonesia., 4(1), 1-10

Zhang, P., Tang, Y., Li, N.G., Zhu, Y., Duan, J.A. 2014. Bioactivity and Chemical Synthesis of Caffeic Acid Penethyl Ester and Its Derivates. Mol., 16458-16476. 